\title{
Root and rhizosphere processes-high time to dig deeper
}

\author{
Boris Rewald ${ }^{1}$, Douglas L. Godbold ${ }^{1}$, Omer Falik ${ }^{2}$ and Shimon Rachmilevitch ${ }^{3}$ \\ 1 Department of Forest and Soil Sciences, Forest Ecology, University of Natural Resources and Life Sciences Vienna (BOKU), Vienna, Austria \\ ${ }^{2}$ Mitrani Department of Desert Ecology, Blaustein Institutes for Desert Research, Ben-Gurion University of the Negev, Midreshet Ben-Gurion, Israel \\ ${ }^{3}$ Blaustein Institutes for Desert Research, French Associates Institute for Agriculture and Biotechnology of Drylands, Ben-Gurion University of the Negev, \\ Midreshet Ben-Gurion, Israel \\ *Correspondence: brewald@rootecology.de
}

Edited and reviewed by:

Hendrik Poorter, Forschungszentrum Jülich, Germany

Keywords: root ecology, botany, rhizosphere, plant growth promoting bacteria, mycorrhizae, earthworms, root physiology, root morphology, soil hydrology, root system architecture, carbon sequestration, root traits, soil science, crop breeding, drought tolerance, heavy metals, lead, aluminum, ectomycorrhizae, root system model, ecophysiology of plants, root dynamics, deep roots, coarse roots

The purpose of the research topic "Ecophysiology of root systemsenvironment interactions" was to shed light on belowground processes - in an effort to further enhance its understanding, but also to increase the awareness of the research community and funding bodies toward this utmost important part of plants and ecosystems.

Why is it important to increase our understanding and awareness? The new challenge of global climate change is driven by an increase in atmospheric $\mathrm{CO}_{2}$ levels, a factor which in itself affects plant and root growth, but is also expected to increase the intensity of climatic and edaphic extremes. In addition, other stresses such as salinization and heavy metal contamination of soils are either increasing or continue to persist world-wide. To secure crop yield and soil quality, and to understand the functioning, and thus the resilience and resistance of pristine ecosystems under changing environmental conditions, an increased understanding of acclimation and adaptation processes is imperative. In the past, plant sciences' research has focused predominantly on parameters above ground-resulting in disproportional less knowledge regarding root systems and the way root system functioning is affected by both internal and external factors. Similarly, soil scientists have often preferred studying bulk soil over the rhizosphere and as a consequence root-driven soil processes are still far less studied. Because it is "better to light a candle than curse the darkness" (Herron et al., 2013), this research topic puts research on root and rhizosphere into the spotlight.

Increased net photosynthesis and decreased shoot nitrogen and water use under elevated $\mathrm{CO}_{2}$ can alter source-sink relations of plant organs. In this research topic, Easlon and Bloom (2013) emphasize the important role of root-shoot signaling for plant acclimation to increasing $\mathrm{CO}_{2}$ levels. Addressing water availability, Carminati (2013) shows that fast and almost immediate rewetting after soil drought took place in the rhizosphere of distal maize root segments while the rhizosphere of higher root orders possessed slower rewetting. The difference in the speed of rewetting for different root orders, may possibly be an adaptation strategy to drought periods, increasing the water uptake by young root segments and hydraulically disconnecting the older ones. Two comprehensive reviews shed light on the influence and interplay of heavy metals on/with root systems, and influence of root traits on whole plant stress resistance. In one review,
Fahr et al. (2013) address the wide range of tolerance mechanism of roots against lead exposure, while in another review Brunner and Sperisen (2013) focus on the current understanding of aluminium exclusion and tolerance mechanisms in woody plants.

The response of roots to abiotic stress can be modified by some root-associated bacteria and fungi. This is expressed as modification of root morphology and whole plant ecophysiology, which often enhances plant growth under stress (Alavi et al., 2013; Vacheron et al., 2013). Increasing knowledge of bacterial nutrition in the rhizosphere will further increase the understanding of the role of certain bacteria as plant-growth promoters (Lopez-Guerrero et al., 2013). Similarly, mycorrhizal symbionts are very important for soil exploration; in this context, Lang et al. (2013) report on spatial structuring of ectomycorrhizal assemblages within beech root systems. While earthworms often improve soil structure and nutrient availability, Arnone and Zaller (2014) report decreasing grass root length densities under increasing earthworm densities, with yet unknown consequences for nutrient foraging.

Besides abiotic stress, root-microbe and root-fauna interactions, plant-plant interactions below ground are common and can influence plant performance considerably. For example, Bolte et al. (2013) show that beech fine roots are facilitated in the presence of spruce roots-possibly by lowering the competitive pressure (for resources) compared to intraspecific competition. While information on the mechanisms of belowground neighbor perception is rare, Schmid et al. (2013) outline that Arabidopsis roots perceive neighboring roots or their associated microorganisms by a mechanism that involves the induction of pathogenesis-related proteins. Their findings reveal that belowground neighbor detection may occur independently of resource depletion, possibly allowing roots to anticipate future competition.

In the past years an increasing awareness has developed that understanding root traits will help to understand plant functioning. Since resources are acquired by the root system, breeding for crops with root traits/phenotypes increasing water and nutrient acquisition should increase yields on infertile soils and under a range of other abiotic stresses such as drought (Comas et al., 2013; White et al., 2013). In doing so, a better understanding of how root and root system traits interact to affect soil resource 
acquisition is needed (York et al., 2013). In woody plants, our understanding of species- or even variety-specific root trait plasticity under variable environments and the importance of specific traits such as deep rooting (Laclau et al., 2013; Maeght et al., 2013 ) is even more scarce than in crop plants. A primary reason for this difference in understanding being the challenges caused by more complex, difficult-to-access, perennial root systems. Fortunately, several studies of this research topic shed light on the variability/plasticity of (some) fine root traits of several tree species with ontogeny, and/or under different environmental or management conditions. For example, Noguchi et al. (2013) showed that $\mathrm{N}$-fertilization had a more pronounced effect on Cryptomeria japonica root morphology than on root biomass. Studying ectomycorrhizal short roots, Ostonen et al. (2013) found that morphological root traits of late-successional spruce are as plastic as that of pioneer silver birch, and that differences between root traits of the two species was less under more temperate conditions compared to more boreal conditions. The work of Tobner et al. (2013) evidenced that the responses to ontogeny or soil conditions are species but also trait dependent. Hajek et al. (2013) found distinct intraspecific variation in most root traits among seven Poplar demes. As highlighted by Fort (2013), their results challenge the existence of well-defined species-specific trait values, but rather highlight the existence of pronounced within-species trait diversity linked to genetic differentiation. While manuscripts in this research topic address a plethora of root traits, increasing efforts are also required to understand root system branching in situ and in silica (Bodner et al., 2013) and to develop meaningful classification approaches for functional units within root systems. Bodner and colleagues showed that statistical classification methods can integrate knowledge on morphological traits obtained with different methods and at various scales. Currently morphology seems to be the most promising basis for classification approaches due to its wide use. However, the lack of consensus about fine root classification (and a clear nomenclature), and the importance of specific traits constrains the development of a unified framework toward a "root economics spectrum" as was achieved for both leaves (see e.g., Poorter et al., 2014 and references therein) and wood. In addition, more suitable methods are needed allowing advanced root research; here Danjon et al. (2013) describe a modeling approach to estimating root loss during tree root system sampling, and Faget et al. (2013) introduce a combined root fluorescence and planar Optode technique which allows to distinguish between different plant species grown in natural soil and to measure the impact of root (exudates) on the soil environment. Using lightemitting soil microbial "biosensors," Herron et al. (2013) were able to determine hotspots of microbial growth along the growing root. The growth of these microbial hotspots was supported by high carbon availability.

In addition to articles on basic research which often accentuate the uncertainties in the field of root research, some articles already outline the application of knowledge of root traits in applied plant production systems. The study by Kerbiriou et al. (2013) provides first evidence that "robustness" and head growth rates of lettuce cultivars are related to the size of the root system. Terzaghi et al. (2013) investigated C and N concentrations in Fagus sylvatica fine roots in relation to different stand characteristics resulting from conversion of coppiced forests to high forests. The fine-root C:N ratio was higher in coppiced than in converted stands and showed an inverse relationship with fine-root turnover rate, illustrating a significant change of fine-root status under different management practices-likely influencing e.g., the $\mathrm{C}$ sequestration potential of stands. Chairungsee et al. (2013) revealed a significant negative correlation between fine root dynamics and production in rubber plantations. Latex harvesting might disturb carbon dynamics in the whole tree, far beyond the trunk; the results emphasize the impact of root systems on the carbon budget and thus yield of tree crops plantations.

When taken as a whole, the 28 contributions to this research topic cover many, although by no means all, aspects of root and rhizosphere research. The number of articles collected within a relatively short period of time, and other recently published special issues addressing root-environmental interactions (e.g., Annals of Botany, 2012, 2013; New Phytologist, 2013), demonstrate that the awareness about root and rhizosphere research and its applicability is rising.

\section{ACKNOWLEDGMENT}

We would like to thank the authors, reviewers and the Frontiers Editorial Office for their support in creating this special topic, and hope fellow scientists and grant managers will enjoy reading it as much as we enjoyed editing it.

\section{REFERENCES}

Alavi, P., Starcher, M., Zachow, C., Müller, H., and Berg, G. (2013). Rootmicrobe systems: the effect and mode of interaction of Stress Protecting Agent (SPA) Stenotrophomonas rhizophila DSM14405T. Front. Plant Sci. 4:141. doi: 10.3389/fpls.2013.00141

Annals of Botany. (2012). Special issue: root biology. Ann. Bot. 110, 201-534.

Annals of Botany. (2013). Special issue: matching roots to environment. Ann. Bot. $112,207-464$.

Arnone, J. A., and Zaller, J. G. (2014). Earthworm effects on native grassland root system dynamics under natural and increased rainfall. Front. Plant Sci. 5:152. doi: $10.3389 /$ fpls.2014.00152

Bodner, G., Leitner, D., Nakhforoosh, A., Sobotik, M., Moder, K., and Kaul, H.P. (2013). A statistical approach to root system classification. Front. Plant Sci. 4:292. doi: 10.3389/fpls.2013.00292

Bolte, A., Kampf, F., and Hilbrig, L. (2013). Space sequestration below ground in old-growth spruce-beech forests-signs for facilitation?. Front. Plant Sci. 4:322. doi: 10.3389/fpls.2013.00322

Brunner, I., and Sperisen, C. (2013). Aluminium exclusion and aluminium tolerance in woody plants. Front. Plant Sci. 4:172. doi: 10.3389/fpls.2013.00172

Carminati, A. (2013). Rhizosphere wettability decreases with root age: a problem or a strategy to increase water uptake of young roots? Front. Plant Sci. 4:298. doi: 10.3389/fpls. 2013.00298

Chairungsee, N., Gay, F., Thaler, P., Kasemsap, P., Thanisawanyangura, S., Chantuma, A., et al. (2013). Impact of tapping and soil water status on fine root dynamics in a rubber tree plantation in Thailand. Front. Plant Sci. 4:538. doi: 10.3389/fpls.2013.00538

Comas, L., Becker, S., Cruz, V. M. V., Byrne, P. F., and Dierig, D. A. (2013). Root traits contributing to plant productivity under drought. Front. Plant Sci. 4:442. doi: 10.3389/fpls.2013.00442

Danjon, F., Caplan, J. S., Fortin, M., and Meredieu, C. (2013). Descendant root volume varies as a function of root type: estimation of root biomass lost during uprooting in Pinus pinaster. Front. Plant Sci. 4:402. doi: 10.3389/fpls.2013. 00402

Easlon, H. M., and Bloom, A. J. (2013). The effects of rising atmospheric carbon dioxide on shoot-root nitrogen and water signaling. Front. Plant Sci. 4:304. doi: 10.3389/fpls.2013.00304 
Faget, M., Blossfeld, S., Von Gillhaußen, P., Schurr, U., and Temperton, V. M. (2013). Disentangling who is who during rhizosphere acidification in root interactions: combining fluorescence with optode techniques. Front. Plant Sci. 4:392. doi: 10.3389/fpls.2013.00392

Fahr, M., Laplaze, L., Bendaou, N., Hocher, V., El Mzibri, M., Bogusz, D., et al. (2013). Effect of lead on root growth. Front. Plant Sci. 4:175. doi: $10.3389 /$ fpls.2013.00175

Fort, F. (2013). Intraspecific functional trait variation and performance of Populous tremuloides. Front. Plant Sci. 4:527. doi: 10.3389/fpls.2013. 00527

Hajek, P., Hertel, D., and Leuschner, C. (2013). Intraspecific variation in root and leaf traits and leaf-root trait linkages in eight aspen demes (Populus tremula and P. tremuloides). Front. Plant Sci. 4:415. doi: 10.3389/fpls.2013. 00415

Herron, P. M., Gage, D. J., Arango Pinedo, C., Haider, Z. K., and Cardon, Z. G. (2013). Better to light a candle than curse the darkness: illuminating spatial localization and temporal dynamics of rapid microbial growth in the rhizosphere. Front. Plant Sci. 4:323. doi: 10.3389/fpls.2013.00323

Kerbiriou, P. J., Stomph, T.-J., Lammerts Van Bueren, E. T., and Struik, P. C. (2013). Influence of transplant size on the above- and below-ground performance of four contrasting field-grown lettuce cultivars. Front. Plant Sci. 4:379. doi: 10.3389/fpls.2013.00379

Laclau, J.-P., Silva, E. A. D., Rodrigues Lambais, G., Bernoux, M., Le Maire, G., Stape, J. L., et al. (2013). Dynamics of soil exploration by fine roots down to a depth of $10 \mathrm{~m}$ throughout the entire rotation in Eucalyptus grandis plantations. Front. Plant Sci. 4:243. doi: 10.3389/fpls.2013.00243

Lang, C., Finkeldey, R., and Polle, A. (2013). Spatial patterns of ectomycorrhizal assemblages in a monospecific forest in relation to host tree genotype. Front. Plant Sci. 4:103. doi: 10.3389/fpls.2013.00103

Lopez-Guerrero, M., Ormeño-Orrillo, E., Rosenblueth, M., Martinez-Romero, J., and Martinez-Romero, E. (2013). Buffet hypothesis for microbial nutrition at the rhizosphere. Front. Plant Sci. 4:188. doi: 10.3389/fpls.2013.00188

Maeght, J.-L., Rewald, B., and Pierret, A. (2013). How to study deep roots-and why it matters. Front. Plant Sci. 4:299. doi: 10.3389/fpls.2013.00299

New Phytologist. (2013). Virtual special issue: scaling root processes - global impacts. New Phytol.

Noguchi, K., Nagakura, J., and Kaneko, S. (2013). Biomass and morphology of fine roots of sugi (Cryptomeria japonica) after three years of nitrogen fertilization. Front. Plant Sci. 4:347. doi: 10.3389/fpls.2013.00347

Ostonen, I., Rosenvald, K., Helmisaari, H.-S., Godbold, D., Parts, K., Uri, V., et al. (2013). Morphological plasticity of ectomycorrhizal short roots in Betula sp. and Picea abies forests across climate and forest succession gradients: its role in changing environments. Front. Plant Sci. 4:335. doi: 10.3389/fpls.2013.00335

Poorter, H., Lambers, H., and Evans, J. R. (2014). Trait correlation networks: a whole-plant perspective on the recently criticized leaf economic spectrum. New Phytol. 201, 378-382. doi: 10.1111/nph.12547

Schmid, C., Bauer, S., Müller, B., and Bartelheimer, M. (2013). Belowground neighbor perception in Arabidopsis thaliana studied by transcriptome analysis: roots of Hieracium pilosella cause biotic stress. Front. Plant Sci. 4:296. doi: 10.3389/fpls.2013.00296

Terzaghi, M., Montagnoli, A., Di Iorio, A., Scippa, G. S., and Chiatante, D. (2013). Fine-root carbon and nitrogen concentration of European beech (Fagus sylvatica L.) in Italy Prealps: possible implications of coppice conversion to high forest. Front. Plant Sci. 4:192. doi: 10.3389/fpls.2013.00192

Tobner, C. M., Paquette, A., and Messier, C. (2013). Interspecific coordination and intraspecific plasticity of fine root traits in North American temperate tree species. Front. Plant Sci. 4:242. doi: 10.3389/fpls.2013.00242

Vacheron, J., Desbrosses, G., Bouffaud, M.-L., Touraine, B., Moënne-Loccoz, Y., Muller, D., et al. (2013). Plant growth-promoting rhizobacteria and root system functioning. Front. Plant Sci. 4:356. doi: 10.3389/fpls.2013.00356

White, P. J., George, T. S., Dupuy, L. X., Karley, A. J., Valentine, T. A., Wiesel, L., et al. (2013). Root traits for infertile soils. Front. Plant Sci. 4:193. doi: 10.3389/fpls.2013.00193

York, L. M., Nord, E., and Lynch, J. (2013). Integration of root phenes for soil resource acquisition. Front. Plant Sci. 4:355. doi: 10.3389/fpls.2013.00355

Conflict of Interest Statement: The authors declare that the research was conducted in the absence of any commercial or financial relationships that could be construed as a potential conflict of interest.

Received: 04 April 2014; accepted: 28 May 2014; published online: 12 June 2014. Citation: Rewald B, Godbold DL, Falik O and Rachmilevitch S (2014) Root and rhizosphere processes-high time to dig deeper. Front. Plant Sci. 5:278. doi: 10.3389/fpls. 2014.00278

This article was submitted to Functional Plant Ecology, a section of the journal Frontiers in Plant Science.

Copyright (c) 2014 Rewald, Godbold, Falik and Rachmilevitch. This is an openaccess article distributed under the terms of the Creative Commons Attribution License (CC BY). The use, distribution or reproduction in other forums is permitted, provided the original author(s) or licensor are credited and that the original publication in this journal is cited, in accordance with accepted academic practice. No use, distribution or reproduction is permitted which does not comply with these terms. 